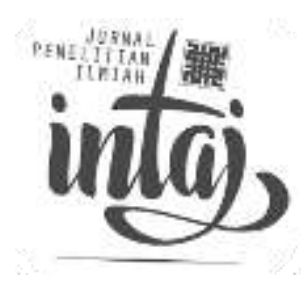

\title{
Pola Komunikasi Driver Ojek Online Grabbike pada Pelayanan Customer di Kota Malang
}

\author{
M oh. A miruddin (mohamiruddin88@gmail.com) \\ Institut Agama Islam AI-Qolam M alang
}

(Received: Juni 2019 / Revised: Agustus 2019 / Accepted: September 2019)

\begin{abstract}
Transportation is an important part of the daily activities of the community. Along with the rapid development of technology, transportation facilities have also developed, one of which is the emergence of online transportation. Grab is one of the online transportation applications that circulate in various regions in Indonesia. One of its features, GrabBike, is that drivers are the main center in terms of serving the customers. Therefore, a good communication is needed. Communication is often an obstacle for drivers in serving customers. It is necessary to know the communication patterns used by the drivers in communicating to the customers. This research is conducted using qualitative data collection through observation and interviews. the results obtained are that GrabBike online motorcycle taxi drivers using three communication patterns in service to customers including linear or one-way communication patterns, circular or two-way communication patterns, and helical or spiral communication patterns.
\end{abstract}

Keywords: communication, pattern, online taxi bike, driver 


\section{PENDAHULUAN}

Setiap perilaku manusia adalah bentuk komunikasi, perilaku didorong atau memberi dorongan seseorang untuk berkomunikasi, ada perbedaan cara berkomunikasi antara komunikator kepada teman sebaya, orang tua, tetangga, atasan, bawahan atau orang yang baru dikenal, bagaimana pemilihan kata yang tepat, bagaimana posisi tubuh dan intonasi bicara, komunikasi memahamkan seseorang untuk memahami perilaku manuisa, minimal dirinya sendiri, komunikasi juga memahamkan dimana kita sedang berada. ${ }^{1}$

Dalam fenomena ini komunikasi menjadi hal yang tak terhindarkan peristiwa komunikasi dapat terjadi di mana, kapan dan oleh siapa saja. komunikasi sering dilakukan dalam organisasi maupun di luar organisasi, apakah organisasi tersebut berbentuk lembaga pendidikan, sering bersifat antarpribadi (interpersonal communication), ataupun berkelompok (group communication). Peristiwa komunikasi ini telah menjadi istilah umum, dimana maksud dan tujuannya adalah untuk mendeskripsikan sejumlah proses komunikasi antar manusia.

Perkembangan teknologi internet yang cukup pesat memberikan perubahan sosial masyarakat. Banyak bisnis mulai bermunculan dengan memanfaatkan perkembangan teknologi informasi tersebut, salah satunya adalah kemunculan bisnis penyedia layanan jasa berbasis aplikasi. Salah satunya, adalah kemunculan transportasi berbasis online yang ternyata dapat memberikan solusi dan menjawab berbagai kekhawatiran masyarakat akan layanan transportasi umum. Kemacetan Kota dan ketakutan masyarakat dengan keamanan transportasi umum dijawab dengan kehadiran aplikasi transprtasi online yang memberikan kemudahan dan kenyamanan bagi penggunanya²

Ojek Online ini menjawab kekhawatiran masyarakat tentang jaminan keamanan di dalam transportasi umum. Ojek Online ini menjawab kekhawatiran masyarakat dengan kelebihan aplikasi berbasis data, dimana masyarakat bisa mengetahui identitas drivernya. Dengan kelebihan ini, masyarakat bisa mengetahui siapa yang akan menjadi driver ojek pesanannya, lengkap dengan data diri driver bersangkutan. Dalam aplikasinya, Ojek Online ini sangat mengedepankan faktor keamanan si

${ }^{1}$ Nurrudin, IImu Komunikasi Ilmiah dan Populer, (Jakarta: PT RajaGrafindo Persada, 2017), hlm. 15

Arianis Chan, Maulydia Maharani, dan Pratami Wulan Tresna, "Comparison of User Experience on Go-Jek and Grab Mobile Apps: Study on PT. Go-Jek and PT. Grab Indonesia Consumer in DKI Jakarta", dalam Jurnal AdBispreneur Vol. 2, No. 2, Agustus 2017, hlm. 163-164 
pengguna. Biasanya di dalam aplikasi sudah tersedia informasi lengkap tentang pengendara seperti nama, kontak, dan foto pengendara. berbagai kelebihan kelebihan yang ditawarkan Ojek Online ternyata membawa perubahan yang signifikan terhadap kehidupan sosial masyarakat ${ }^{3}$

Komunikasi yang baik juga dibutuhkan dalam pelayanan driver kepada Customer hal yang tidak bisa dihindari adalah etika dalam komunikasi antarpribadi. Dalam menghindari etika dalam berkomunikasi, maka orang akan bersandar pada berbagai macam pembenaran. Dalam pembenaran itu setiap orang tahu bahwa teknik komunikasi tertentu adalah tidak etis jadi tidak perlu dibahas, karena yang penting dalam komunikasi hanyalah masalah kesuksesan maka masalah etika tidak relevan untuk dibicarakan, penilaian etika hanyalah masalah penilaian individu secara pribadi sehingga tak ada jawaban pasti dan menilai etika orang lain menunjukkan sebuah keangkuhan atau hal yang tidak sopan².

Berdasarkan penjelasan yang telah dipaparkan, telah timbul banyak permasalahan yang terjadi pada customer yang ditimbulkan karena pelayanan driver ojek online khususnya dalam hal berkomunikasi. Komunikasi yang dilakukan driver ojek online bisa mempengaruhi kenyamanan customer. Untuk mengetahui dan mengkaji lebih dalam bagaimana pola komunikasi yang terjadi antara driver dan customer sehingga membentuk suatu pola komunikasi yang digunakan dan efektif, maka judul penelitian ini adalah "Pola Komunikasi Driver Ojek Online GrabBike pada Pelayanan Customer di Kota Malang". Penelitian ini memfokuskan pada bagaimana pola komunikasi yang dilakukan Driver ojek online GrabBike pada customer di Kota M alang.

\section{METODE PENELITIAN}

Penelitian yang berjudul "Pola Komunikasi Driver Ojek Online GrabBike pada Pelayanan Customer di Kota Malang" ini menggunakan jenis penelitian deskriptif. Penelitian deskriptif bertujuan menggambarkan secara sistematik dan akurat fakta dan karakteristik mengenai populasi atau mengenai bidang tertentu. Penelitian ini

Wiratri Anindhita, "Analisis Penerapan Teknologi Komunikasi Tepat Guna Pada Bisnis Transportasi Ojek Online: Studi Pada Bisnis Gojek Dan Grab Bike Dalam Penggunaan Teknologi Komuniasi Tepat Guna Untuk Mengembangkan Bisnis Transportasi", Prosiding Seminar Nasional INDOCOMPAC Universitas Bakrie, 2016, hlm. 713

Edi Harapan, Komunikasi Antar Pribadi Perilaku Insani Dalam Organisasi Pendidikan, (Jakarta: PT RajaGrafindo Persada, 2014), hIm. 173-174 
berusaha menggambarkan situasi atau kejadian ${ }^{5}$. Dalam penelitian dengan judul "Pola Komunikasi Driver Ojek Online GrabBike pada Pelayanan Customer di Kota Malang" ini peneliti menggunakan wawancara dan pengamatan untuk mendeskripsikan atau menggambarkan serta menganalisis fenomena, peristiwa dan sikap driver ojek online pada customer sebagai data atau informasi untuk mendapatkan suatu pola komunikasi yang terjadi antara driver ojek online dan customer.

Untuk mendapatkan kelengkapan data yang sesuai dengan penelitian maka teknik pengumpulan data dengan wawancara, observasi, serta dokumentasi. Teknik pengumpulan data dalam penelitian ini yaitu melakukan wawancara mendalam (in depth interview) kepada subjek penelitian yakni driver Grabbike di Kota Malang dengan jumlah empat orang yang dipilih secara random, dan juga kepada customer sejumlah empat orang yang juga dipilih secara random mengenahi data yang dibutuhkan sehubungan dengan pola komunikasi antara driver ojek online GrabBike pada pelayanan custome, rsedangkan Observasi pada penelitian ini dilakukan untuk melengkapi data-data yang diperoleh melalui wawancara dan untuk memperoleh informasi serta gambaran yang lebih jelas tentang bagaiman pola komunikasi yang terjadi diantara driver ojek online GrabBike pada pelayanan customer diKota M alang dan Dalam penelitian ini dokumentasi yang dilakukan adalah fotofoto kegiatan dalam observasi dan wawancara dengan subjek penelitian. Untuk Uji keabsahan data adalah pemeriksaan keabsahan data yang diperlukan dalam penelitian terutama untuk kandalan, serta tingkat kepercayaan data yang terkumpu. Uji keabsahan atau validitas data dalam penelitian ini diukur dalam triangulasi data. Triangulasi data adalah pengecekan data dari berbagai sumber dengan berbagai cara, dan waktu ${ }^{6}$ Triangulasi data dalam penelitian ini dengan cara mengcrosscheck data atau informasi yang diproleh melalui wawancara kepada subjek penelitian yakni pihak Grab Malang, serta observasi secara langsung, yang kemudian membandingkan data observasi dan wawancara melalui berbagai sumber data. Dari data tersebut dapat ditarik kesimpulan sebagai jawaban dari rumu-

5 Azwar Saifuddin, Metode Penelitian, (Yogyakarta: Pustaka Pelajar,2015) hlm. 6

${ }^{6} \mathrm{Ibid}, \mathrm{hlm} .241$ 
san masalah yaitu bagaimana pola komunikasi yang terjadi antara driver ojek online pada pelayanan customer di Kota M alang.

\section{TENTANG KOMUNIKASI DAN TRANSPORTASI ONLINE 3.1. Pengertian Komunikasi}

Komunikasi berasal dari bahasa Inggris communication (noun) dan communicate (verb). Keduanya mempunyai arti sama yakni "membuat sama" (to make common). Secara rinci communicate berarti: untuk bertukar pikiran, perasaan, informasi, untuk membuat mengerti, untuk membuat sama, untuk mempunyai hubungan yang simpatik. Sementara itu communication (noun) berarti: pertukaran simbol, pesan pesan atau informasi yang sama, proses pertukaran diantara individu-individu melalui sistem simbol yang sama, seni untuk mengekspresikan gagasan, ilmu pengetahuan tentang pengirman pesan. Dengan demikian kata komunikasi dalam praktiknya akan selalu melibatkan, adanya pesan sebagaialat untuk tukar informasi, terciptanya kebersamaan antara komunikator (pengirim pesan) dengan komunikan (penerima pesan). ${ }^{7}$

Komunikasi adalah suatu proses penyampaian pesan dari seseorang kepada orang lain melalui proses tertentu sehingga tercapai apa yang dimaksudkan atau diinginkan oleh kedua belah pihak. Di dalam komunikasi terkandung maksud atau tujuan yang jelas antara si penyampai atau pengirim pesan (komunikator) dengan si penerima pesan (komunikan). M aksud dan tujuan yang jelas antara kedua belah pihak atau mengurangi gangguan atau ketidakjelasan, sehingga komunikasi yang terjadi akan berjalan secara efektif8.

Proses komunikasi mempunyai komponen dasar sebagai berikut:

1) Pengirim Pesan (Sender)

Pengirim pesan adalah orang yang mempunyai ide-ide atau buah pemikiran untuk disampaikan kepada seseorang dengan harapan dapat dipahami oleh orang-orang yang menerima pesan sesuai dengan apa yang dimaksudkan. Pesan adalah informasi yang akan disampaikan atau diekspresikan oleh pengirim pesan. Pesan dapat berbentuk verbal maupun nonverbal dan pesan akan efektif bila diorganisir secara baik dan jelas.

2) Simbol atau Isyarat

${ }^{7}$ Nurrudin, IImu Komunikasi IImiah..., hIm. 27

${ }^{8}$ Edi Harapan, Komunikasi Antar Pribadi..., hlm. 12 
Pada tahap ini pengirim pesan membuat kode atau simbol sehingga pesannya dapat dipahami oleh orang lain. Kode atau isyarat dapat berupa tanda ( kata-kata, tulisan) yang disepakati untuk maksud tertentu. Bila antara kedua belah pihak memahami makna simbol yang dikirimkan atau digunakan pada proses komunikasi terjadi, maka komunikasi akan berjalan efektif. Sebaliknya bila hanya ada satu pihak yang lain tidak memaknai arti simbol yang disampaikan, maka proses komunikasi tidak akan berjalan efektif.

\section{3) M edia atau Perantara}

M edia sering diterjemahkan sebagai perantara antara satu pihak kepada pihak lain. Di dalam proses berkomunikasi peran media sangat penting. M edia komunikasi adalah semua sarana yang dipergunakan untuk memproduksi, mereproduksi, mendistribusikan atau menyebarkan dan menyampaikan informasi. Secara sederhananya, media komunikasi dimaksudkan sebagai perantara atau 'jembatan' dalam menyampaikan informasi.

\section{4) M engartikan Kode atau Isyarat}

Setelah pesan diterima memalui indra (telinga, mata dan sebagainya) maka si penerima pesan harus dapat mengartikan simbol atau kode dari pesan tersebut, sehingga dapat dimengerti atau dipahaminya. Kemampuan mengartikan kode oleh para pihak yang sedang menjalin komunikasi juga menjadi hal yang penting. Oleh sebab itu, penggunaan kode harus dipahami oleh kedua belah pihak yang sedang menjalin komunikasi. Kegagalan dalam proses komunikasi sering kali disebabkan oleh kegagalan para pihak dalam mengartikan kode yang dikirim maupun kode yang diterima.

5) Penerima Pesan (receiver)

Penerima pesan dalam komunikasi disebut sebagai receive, yaitu pihak yng menjadi sasaran pesan yang dikirimkan pleh sumber (komunikator). Reciver juga bisa disebut dengan istilah khalayak, sasaran, pembaca, pendengar, pemirsa, audience, decoder atau komunikan. Penerima pesan merupakan salah satu aktor dari proses komunikasi. Oleh karena itu, unsur penerima pesan tidak boleh diabaikan, karena berhasil atau tidaknya suatu proses komunikasi sangat ditentukan oleh penerima pesan. Penerima pesan adalah orang yang dapat memahami pesan dari si pengirim meskipun dalam bentuk kode atau isyarat tanpa mengurangi arti pesan yang dimaksudkan oleh pengirim.

6) Balikan (feedback) 
Balikan atau umpan balik adala isyarat atau tanggapan yang berisi atau tanggapan yang berisi kesan dari penerima pesan alam bentuk verbal maupun nonverbal. Tanpa balikan seorang pengirim pesan akan tidak akan tahu dampak pesannya terhadap si penerima pesan. $\mathrm{H}$ al ini penting bagi manajer atau pengirim pesan untuk mengetahi apakah pesan sudah diterima dengan pemahaman yang benar dan tepat. Balikan dapat disampaikan oleh penerima pesan atau orang lain yang bukan penerima pesan. Balikan yang disampaikan oleh penerima pesan pada umumnya merupakan balikan langsung yang mengandung pemahaman atas pesan tersebut dan sekaligus mengetahui apakah pesan itu akan dilaksanakan atau tidak.

7) Gangguan

Gangguan bukan merupakan bagian dari proses komunikasi akan tetapi mempunyai pengaruh dalam proses komunikasi, karena pada setiap situasi hampir selalu ada hal yang merintangi atau menghambat komunikasi sehingga penerima salah menafdirkan pesan yang diterimanya.

\subsection{Pola Komunikasi}

Soejarto memaparkan pola komunikasi adalah suatu gambaran yang sederhana dari proses komunikasi yang memperlihatkan kaitan antara satu komponen komunikasi dengan komponen lainnya. Jadi, pola komunikasi diartikan sebagai bentuk atau pola hubungan dua orang atau lebih dalam proses penerimaan cara yang tepat sehingga pesan yang dimaksud dapat dipahami. M odel adalah respresentasi suatu fenomena, baik nyata maupun abstrak, dengan menonjolkan unsurunsur terpenting fenomena tersebut. M odel jelas bukan fenomena itu sendiri. Sebagai alat untuk menjelaskan fenomena komunikasi, model mempermudah penjelasan tersebut. Gordon W iseman dan Larry Barker ${ }^{9}$ dalam M ulyana menjelaskan bahwa model komunikasi mempunyai tiga fungsi : pertama, melukiskan proses komunikasi; kedua, menunjukka hubungan visual; dan ketiga, membantu dalam menemukan dan memperbaiki kemacetan komunikasi. Sedangkan Deussch dalam Mulyana menyebutkan bahwa model mempunyai empat fungsi: mengorganisasikan (kemiripan data dan hubungan) yang tadinyatidak teramati; heuristik (menunjukkan fakta-fakta dan metode baru yang tidak diketahui); prediktif, memungkinkan peramalan dari sekedar tipe ya atau tidak hingga yang kuantitatif yang berkenan dengan kapan dan berapa banyak; pengukuran, mengukur fenomena yang diprediksi.

Deddy Mulyana, Ilmu Komunikasi: Suatu Pengantar, (Bandung: PT Rosdakarya, 2008), hlm. 131-133 
M odel atau Pola mencoba menyederhanakan fenomena komunikasi dengan mempresentasikan secara abstrak ciri-ciri yang dianggap penting saja. Windahl dan McQuail (1995) dalam Nurudin menyatakan setidaknya, adad sekitar 45 model komunikasi. Banyaknya model ini dimungkinkan karena setiap orang juga punya hak membuat model. Namun demikian dari sekian puluh model-model komunikasi tersebut bisa dikelompokan menjadi tiga jenis besar, yakni: (1) Model komunikasi linear atau satu arah; (2) Model komunikasi sirkuler atau dua arah; dan (3) M odel komunikasi spiral atau helical.

Berikut penjelasan dari masing-masing model:

1) Model komunikasi linear atau satu arah

M odel komunikasi linear atau satu arah pesannya hanya satu arah saja dari pembicara kepada komunikan. Komunikan umumnua tidak bisa memberikan reaksi spontan (umpan balik) sebagaimana komunikasi antara dua orang. Komunikan akhirnya hanya bersifat pasif, mendengarkan saja sementara yang aktif adalah kominikatornya. Salah satu asumsi model komunikasi linear bahwa komunikan itu pasif dan menerima pesan apa adanya dari komunikator, dalam kasus seperti ini contoh komunikasi linear atau satu arah adalah proses kampanye pemilihan calon presiden.

2) Model komunikasi sirkuler atau dua arah

Komunikasi sirkuler/dua arah dilakukan oleh dua orang atau lebih secara tatap muka. M aka kedudukan komunikator dan komunikan sama. Artinya, dua orang yang sedang berbicara tidak bisa dibedakan mana komunikator, mana komunikan. A da timbal balik antara komunikator dan juga komunikan.

3) Model Komunikasi spiral atau helical

Komunikasi ini memiliki hubungan dengan komunikasi sebelumnya dan apa yang dikomunikasikan sekarang akan mempengaruhi komunikasi selanjutnya. Proses yang terus menerus saling mempengaruhi disebut dengan model spiral atau helical. Model helical (berasal dari kata helix) dikenalkan oleh Frank Dance pada tahun 1967. Model ini juga dikenal dengan Dance's Helix model. Dance menunjukkan bahwa komunikasi itu sebagai proses dinamis dan bukan sebuah proses linear. Model spriral ini mencoba menggambarkan bagaimana aspek komunikasi yang berbeda dari suatu proses komunikasi selalu berubah dari waktu ke waktu. Intinya bahwa proses komunikasi bergerak secara dinamis menuju suatu titik yang tidak ada ujungnya. Proses komunikasi dimulai dari bagian bawah yang sangat kecil, kemudian bergerak keatas menjadi lebih besar sampai bagaian atas ampai tidak tau 
ujungnya. Bagian kecil tersebut mempengaruhi proses komunikasi selanjutnya dan seterusnya samapi level paling atas.

Dalam teori yang sudah dijelaskan peneliti mengambil pola komunikasi sirkuler atau dua arah, karena pola komunikasi ini memiliki keterkaitan dengan penelitian pola komunikasi driver ojek online.

\subsection{Transportasi Ojek Online}

Transportasi adalah kegiatan pemindahan penumpang dan barang dari satu tempat ke tempat lain. Dalam transportasi terdapat unsur pergerakan (movement), dan secara fisik terjadi perpindahan tempat atas barang atau penumpang dengan atau tanpa alat angkut ke tempat lain. Pejalan kaki adalah perpindahan orang tanpa alat angkut. ${ }^{10}$

Ojek online merupakan angkutan umum yang sama dengan ojek pada umumnya yang menggunakan sepeda motor sebagai sarana pengangkutan. Namun ojek online dapat dikatakan lebih maju karena telah terintegrasi dengan kemajuan teknologi. Ojek online merupakan ojek sepeda motor yang menggunakan teknologi dengan memanfaatkan aplikasi pada smartphone yang memudahkan pengguna jasa untuk memanggil pengemudi ojek tidak hanya dalam hal sebagai sarana pengangkutan orang dan/atau barang namun juga dapat dimanfaatkan untuk membeli barang bahkan memesan makanan sehingga dalam masyarakat global terutama di Kota-Kota besar dengan kegiatan yang sangat padat dan tidak dapat dipungkiri masalah kemacetan selalu menjadi polemik, ojek online ini hadir untuk memudahkan masyarakat dalam melakukan kegiatan sehari-hari dengan mengedepankan teknologi yang semakin maju. ${ }^{11}$

\section{HASIL PENELITIAN}

Berdasarkan penelitian yang dilakukan dengan mewawancarai subjek penelitian yaitu driver ojek online GrabBike dan juga customer GrabBike di Kota Malang, dengan total sebanyak delapan orang. M asing-masing diambil secara random, yaitu empat orang perwakilan dari driver ojek online GrabBike dan empat orang perwakilan dari customer. Begitu juga melalui observasi secara langsung serta mencari

Rafael \& Billy, "Pengaruh Harga dan Promosi Grab Terhadap Brand Image yang Mempengaruhi Keputusan Pembelian Konsumen Pengguna Transportasi Berbasis Online" dalam Jurnal Riset Manajemen dan Bisnis (JRMB) Fakultas Ekonomi UNIAT, Vol. 1. No. 3 tahun 2013, hlm. 120

${ }^{11}$ Wiratri Anindhita, “Analisis Penerapan Teknologi..., hlm. 713 
dari beberapa literatur yang berkaitan dengan masalah yang diteliti. Data yang telah diperoleh selanjutnya dianalisana dengan teknik pengumpulan data kualitatif. Sehingga data yang diperoleh dapat dianalisis dan dideskripsikan secara detail yang menciptakan suatu gambaran dari bagaimana pola komunikasi yang terjadi antara driver ojek online Grabbike pada pelayanan customer di Kota M alang.

Seperti yang sudah dijelaskan pada teori komunikasii pada bagian sebelumnya bahwa komunikasi merupakan elemen yang sangat penting dalam berlangsungnya suatu interaksi sosial. Pentingnya pelayanan yang baik bisa mempengaruhi kenyamanan seorang customer, dalam praktiknya hal yang sangat berpengaruh dalam pelayanan driver pada customer adalah sebuah komunikasi yang baik. Driver dan customer melakukan cara komunikasi maupun interaksi satu sama lain sehingga membentuk suatu pola komunikasi yang berbeda-beda atau beragam. Setiap individu entah itu driver ataupun customer bisa mempengaruhi pola komunikasi yang digunakan. Pola merupakan respresentasi suatu fenomena, baik nyata maupun abstrak, dengan menonjolkan unsur-unsur terpenting fenomena tersebut. Pola jelas bukan fenomena itu sendiri. Sebagai alat untuk menjelaskan fenomena komunikasi, pola mempermudah penjelasan tersebut. Pada Bab II telah dijelaskan bahwa macam macam pola komunikasi menurut Nurudin ${ }^{12}$ yaitu:

\subsection{Pola Komunikasi Linier atau satu arah}

M odel komunikasi linear atau satu arah pesannya hanya satu arah saja dari pembicara kepada komunikan. Komunikan umumnya tidak bisa memberikan reaksi spontan (umpan balik) sebagaimana komunikasi antara dua orang. Komunikan akhirnya hanya bersifat pasif, mendengarkan saja sementara yang aktif adalah kominikatornya. Salah satu asumsi model komunikasi linear bahwa komunikan itu pasif dan menerima pesan apa adanya dari komunikator. Dalam penelitian ini, pola komunikasi satu arah dapat digambarkan dengan komunikasi yang dilakukan antara driver ojek online Grabbike dan juga customer GrabBike di Kota Malang dimana komunikan lebih banyak mendengarkan dan pasif dalam artian tidak ada respon yang diberikan oleh komunikan Jika digambarkan dengan bagan akan terlihat seperti ini: 

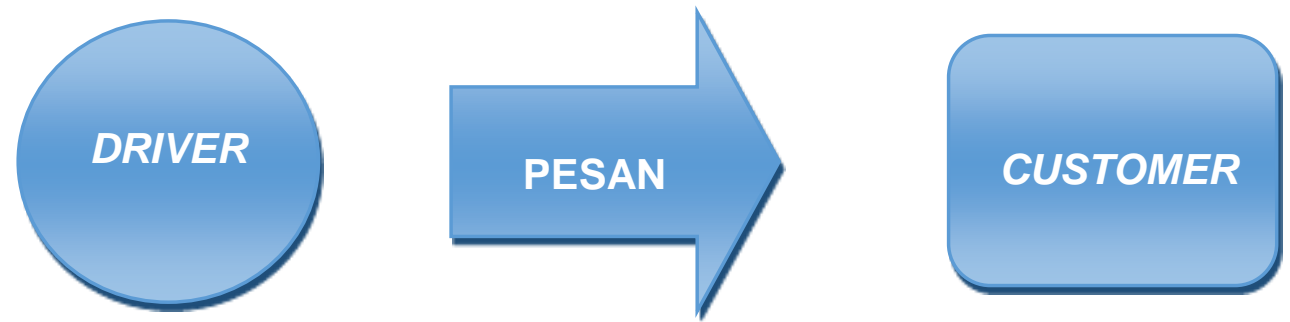

Gambar 1: Bagan Pola Komunikasi Satu Arah

Berikut adalah hasil wawancara kepada Driver ojek online GrabBike dan juga kepada customer GrabBike dengan pertnyaan:

"Bagaimana pola komunikasi yang digunakan driver ojek online GrabBike pada customer?"

M enurut Y onas salah satu D river GrabBike diK ota M alang, mengatakan bahwa,

"Pernah satu arah juga sih, tapi saya nggak pernah paksaan lagi. Kadang saya tanyai gitu, customernya sibuk main hape gitu. Kadang juga nggak menjawab. A da juga yang saya baru nanya, yang di belakang sibuk main hape. Jadi saya nanya kalo udah mau sampeaja"

Gusti, yang juga driver ojek online GrabBike di Kota M alang, mengatakan bahwa,

"Tapi liat customernya juga. Kalo customernya lagi badmood gitu, ya satu arah aja. Biasanya diajak ngobrol diem aja nggak jawab. M ungkin kalau pas lagi diajak ngobrol mereka hapean, jadi khan nggak bisa konsen ngobrolnya."

Pola komunikasi ini diterapkan oleh driver ojek online GrabBike saat melakukan pelayanan di atas kendaraan. Pelayanan yang berupa komunikasi ini selalu dilakukan oleh beberapa driver di Kota M alang. Namun ada beberapa driver yang tidak melakukan pelayanan ini.

M enurut Elin yang salah satu driver ojek online wanita di Kota M alang bahwa,

"kalau saya sih nggak terlalu banyak ngobrol biasanya. Jadi ya sepentingnya aja" 
Sedangkan pola komunikasi satu arah ini juga bisa terjadi dari customer kepada driver. Tidak semua komunikasi yang terjadi selalu dari driver ada pula beberapa kasus bahwa komunikasi satu arah terjadi dari customer kepada driver. $\mathrm{Hal}$ ini bisa diketahui dari hasil wawancara dengan customer GrabBike di Kota M alang.

M enurut Bahrul salah satu customer GrabBike mengatakan bahwa,

"Emm... dikacangin pernah sih. Aku tanyain beberapa kali gitu, aku ajakin ngobrol tapi nggak dijawab. Tapi kayaknya bapaknya lagi sakit."

M enurut H elmi sebagai customer GrabBike mengatakan bahwa,

"Ya, pernah. Kadang khan kalau di jalan kita nggak bisa denger. Drivernya udah ngomong berulang-ulang. Jadi kita khan sungkan kalau nanyain lagi. Jadi ya cuman diiyain aja karena nggak denger. Jadi ya nggak bisa ngobrol enak."

Faktor internal yang timbul dari driver ataupun customer seringkali menjadi faktor utama yang mempengaruhi pola komunikasi satu arah, bisa muncul dari driver ojek online GrabBike yang tidak mendengar atau dalam suasana mood yang tidak baik, ataupun dari customer yang sering mengabaikan komunikasi yang diberikan oleh Driver ojek online GrabBike dengan bermain handphone atau memang dengan sengaja tidak menjawab pertanyaan driver. Namun faktor lain juga bisa muncul dari segi lain seperti komunikasi yang diberikan oleh driver tidak tersampaikan dengan baik karena komunikasi sedang disampaikan diatas kendaraan sehingga kurang diterima dengan baik oleh komunikan (customer), karena akan disebut sebuah komunikasi jika pesan yang disampaikan dapat dipahami dan dimengerti oleh komunikan (customer).

\subsection{Pola Komunikasi Sirkuler atau D ua Arah}

Komunikasi sirkuler atau dua arah dilakukan oleh dua orang atau lebih secara tatap muka. Dalam hal ini, kedudukan komunikator dan komunikan sama. Artinya, dua orang yang sedang berbicara tidak bisa dibedakan mana komunikator, mana komunikan. Ada timbal balik antara komunikator dan juga komunikan. Seorang sumber tidak hanya menjadi komunikator tapi juga komunikan dalam kondisi tertentu. Penerima pesan tidak dianggap pasif hanya dengan menerima informasi atau pesan namun juga melakukan reaksi terhadap pesan tersebut yang sering 
disebut dengan timbal balik.Dalam penelitian ini komunikasi dua arah dapat digambarkan dengan komunikasi yang dilakukan oleh driver ojek online GrabBike pada customer di Kota Malang sudah terjadi timbal balik atau respon sehingga komunikasi sudah dapat berjalan dengan lancar. Jika digambarkan dengan bagan akan terlihat seperti ini:
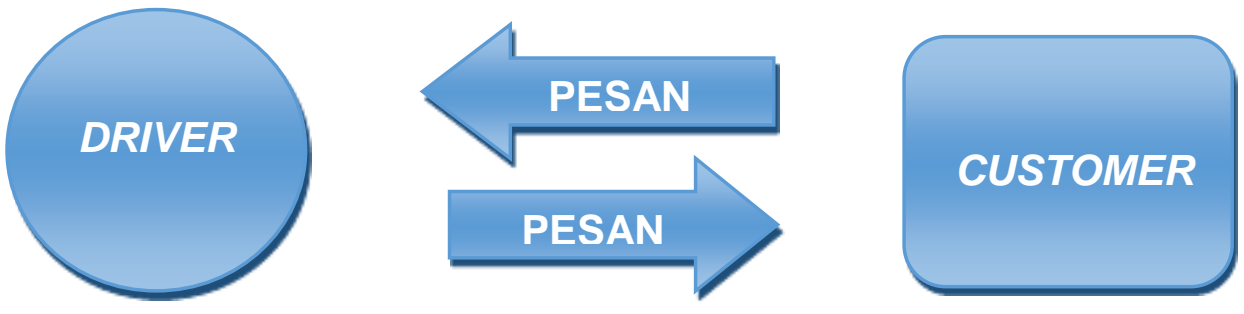

Gambar 2: Bagan Pola Komunikasi Dua Arah

Berikut adalah hasil wawancara kepada Driver ojek online GrabBike dan juga kepada customer GrabBike dengan pertanyaan:

"Bagaimana pola komunikasi yang digunakan driver ojek online GrabBike pada customer?"

Yonas, salah satu driver ojek online di Kota M alang, mengatakan bahwa,

"kalau saya, ya kebanyakan dua arah M bak, karena saya sendiri suka ngomong. Nggak tau kalau driver lain ya. Kalau saya punya template pertanyaan sendiri. Jadi ,saya selalu tanya mau kemana, terus kuliah di mana, jurusan apa gitu. Jadi udah jadi template pertanyaan gitu. Ada beberapa customer yang curhat-curhat gitu."

Gusti, yang juga salah satu driver ojek online di Kota M alang, mengatakan bahwa,

"Kalau pola komunikasi sih biasanya dua arah, soalnya sama-sama ngobrol toh. Ya tergantung sama customernya, tapi ya $80-90 \%$."

Gusti juga mengatakan bahwa,

"Sejauh ini sih setiap customer selalu ada komunikasi. Biasanya mereka yang curhat-curhat. A tau biasanya aku yang sharing. Tapi nggak lancang juga sih. N gobrolnya tetep di koridornya" 
Dalam pola komunikasi dua arah, driver dan juga customer sudah mempunyai komunikasi yang aktif dan ada timbal balik. Ini berarti pesan yang disampaikan komikator dapat direspon, diterima dan dimengerti oleh komunikan, sehingga menimbulkan komunikasi yang baik. Komunikai yang seperti inilah yang dapat menunjang pelayanan driver pada customer karena dapat menimpulkan kenyamanan dan kesan yang baik. $\mathrm{Hal}$ ini dapat diketahui dari perolehan wawancara dengan customer.

Bahrul selaku cutomer driver ojek online mengatakan bahwa,

"Nah, pertama kali naik Grab saya dapet driver yang baik dan sopan. Jadi ya kesan saya baik."

$\mathrm{H}$ al tersebut juga disampaikan oleh driver ojek online. Komunikasi yang baik ini dibangun sejak mereka menerima orderan dari customer; mulai dari pelayanan telephone atau chatting yang baik sehingga membuat nyaman customer dan bisa menimbulkan kesan yang baik.

Gusti, sebagai driver ojek online GrabBike di Kota M alang mengatakan bahwa,

"Pelayanan, pertama jelasnya yang senyum salam sapa sih. Dari chat udah dibikin nyaman yang sopan gitu. Kalau ketemu juga ngobrol yang sopan lah. N ggak di luar koridor. N yamain bahasa mereka juga."

Pola komunikasi ini juga ditanggapi dengan baik oleh customer. Tidak hanya driver saja yang aktif dalam komunikasi sirkuler atau dua arah ini. Customer juga aktif dalam memberikan pesan. Seperti yang disampaikan customer dalam wawancara.

Bahrul, seorang customer ojek online GrabBike, mengatakan bahwa,

"A ku sendiri orangnya kalo lagi sama orang suka ngajakin ngobrol sih, soalnya canggung kalo cuman diem aja"

H elmi seorang customer ojek online GrabBike juga mengatakan bahwa,

"T api nggak memungkiri juga sih kalau mood saya lagi baik. Kadang kalau drivernya diam saya yang ajak bicara. Tapi sering sih dapet driver yang emang enak gitu, yang suka ngajak ngobrol, bercanda gitu. M alah kadang kadang dapet driver yang suka sharing-sharing gitu lah." 
Setiap customer dan driver pasti pernah melakukan komunikasi dua arah ini. Komunikasi antara driver ojek online GrabBike dan juga customer sudah terjadi dengan baik menurut pengaplikasian pola komunikasi sirkuler atau dua arah. U ntuk kendala atau faktor yang dapat mempengaruhi komunikasi salah satunya adalah kendala Bahasa. Jadi, seorang komunikator harus bisa menyesuaikan bahasa yang digunakan. Hal ini diperkuat dengan wawancara yang dilakukan dengan driver ojek online GrabBike.

Yonas, seorang driver ojek online GrabBike di Kota M alang, mengatakan bahwa,

"Kalau saya khan (orang) Jawa Timur, Banyuwangi. Kalau dapet anak Bekasi atau anak Jakarta-an gitu suka kaku kalau ngomong. Jadi, saya pakai Bahasa Indonesia. Biasanya pakai Bahasa Jawa soalnya."

Gusti, seorang driver ojek online GrabBike di Kota M alang, juga menyampaikan bahwa,

"Nyamain bahasa mereka juga. Kalau customer pakai Bahasa Jawa ya pakai Bahasa Jawa. Tapi kalau awal-awal ya pakai Bahasa Indonesia dulu. Baru nantinya nyamain customer gimana."

Tampaknya faktor bahasa yang sering menjadi kendala driver ojek online GrabBike di Kota Malang. Namun hal itu semua bisa diatasi dengan menyamakan bahasa yang digunakan antara kedua belah pihak.

\subsection{Pola Komunikasi Helikal atau Spiral}

Komunikasi ini memiliki hubungan dengan komunikasi sebelumnya, dan apa yang dikomunikasikan sekarang akan mempengaruhi komunikasi selanjutnya. Model spriral ini mencoba menggambarkan bagaimana aspek komunikasi yang berbeda dari suatu proses komunikasi selalu berubah dari waktu ke waktu. Intinya bahwa proses komunikasi bergerak secara dinamis menuju suatu titik yang tidak ada ujungnya. Proses komunikasi dimulai dari bagian bawah yang sangat kecil, kemudian bergerak keatas menjadi lebih besar sampai bagaian atas ampai tidak diketahui ujungnya. Bagian kecil tersebut mempengaruhi proses komunikasi selanjutnya dan seterusnya sampai level paling atas. Jika digambarkan akan terlihat seperti berikut ini:

Titik tak terbatas 
Titik awal

Gambar 3: Bagan Pola Komunikasi Helical atau Spiral

Dalam kasus ini, sedikit dari driver ojek online maupun dari customer yang mengalami pola komunikasi helical atau spiral. Karena komunikasi ini tidak hanya berhenti di suatu titik namun bisa berkelanjutan dan terus berkembang hingga titik yang tak terbatas. Pola komunikasi ini terjadi dari sebuah titik awal. Dalam penelitian ini, titik awal yang dimaksud adalah titik ketika driver pertama kali menerima orderan atau customer yang mendapatkan driver. Namun dari hasil wawancara, salah satu driver dan customer pernah megalami dan sedang mengalami proses pola komunikasi helikal atau spiral ini.

Yonas, seorang driver ojek online GrabBike di Kota M alang, mengatakan bahwa,

"Ada, M bak. Kebetulan saya juga punya pelanggan offline. Jadi, saya ini, M bak, pelanggannya di perumahan. Dia punya perusahaan percetakan. Jadi kadang saya harus jemput gitu. Jadi, saya sering dapat offline.”

Bahrul, seorang customer driver ojek online GrabBike di Kota M alang, mengatakan bahwa,

"M alah pernah dimintai nomor whatsapp sama mas Grab-nya. Ini buat ngelanjutin pembicaraan yang di motor tadi."

Rindha, yang juga seorang customer ojek online GrabBike di Kota M alang, mengatakan bahwa,

"Pernah sih tiba-tiba ada driver yang wa. Ngajak kenalan ngajak ngobrol gitu. Ngelanjutin obrolan yang di motor tadi, gitu."

Pemaparan yang diberikan driver dan customer driver ojek online GrabBike ini merupakan pola komunikasi helical atau spiral. Dapat dijelaskan yang menjadi titik awal adalah saat pertama kali driver menerima orderan. Komunikasi tetap ber- 
lanjut beberapa hari berikutnya dengan cara memesan melalui offline dengan driver yang sama. Kasus yang kedua terjadi antara customer dengan driver. Titik awal terjadi di saat komunikasi terjadi di atas kendaraan lalu berlanjut pada aplikasi chatting. Dua kasus ini mewakili proses pola komunikasi helical atau spiral.

Seperti yang sudah di paparkan tentang pola-pola komunikasi sebelumnya, dapat diketahui bahwa suatu pola komunikasi yang digunakan atau diterapkan oleh driver ojek online adalah ketiga pola tersebut namun yang paling efektif digunakan oleh customer maupun driver adalah komunikasi sirkuler atau dua arah.

Dalam proses komunikasi di dapati pula faktor-faktor penghampat komunikasi seperti yang dipaparkan pada Bab II, faktor faktor penghambat yang mempengaruhi komunikasi menurut Effendy ${ }^{13}$ adalah sebagai berikut:

1) Hambatan sosio-antro-psikologis

Proses komunikasi berlangsung dalam konteks situsional (situasioanal context). Ini berarti bahwa komunikator harus memperhatikan situasi ketika komunikasi dilangsungkan, sebab situasi amat berpengaruh terhadap kelancaran komunikasi, terutama situasi yang berhubungan dengan faktor-faktor sosiologis-antropologispsikologis. Penerapannya dalam penelitian ini bisa dilihat ketika driver harus mengetahui situasi yang sedang terjadi pada customer.

Yonas seorang driver GrabBike mengatakan bahwa,

"Pernah satu arah juga, sih. Tapi saya nggak pernah paksain lagi. Kadang saya tanyai gitu customernya sibuk main hape. Gitu kadang juga nggak menjawab."

Dalam situasi ini, driver maupun customer harus memperhatikan situasi ketika melakukan sebuah komunikasi. Kondisi psikologis dari kedua pihak bisa mempengaruhi berjalannya sebuah komunikasi.

2) Hambatan semantis

Faktor semantis menyangkut bahasa yang dipergunakan komunikator sebagai alat untuk menyalurkan pikiran perasaan kepada komunikan. Demi kelancaran komunikasi, komunikator harus memperhatikan gangguan semantis ini. Jika terjadi salah ucap dapat menimbulkan salah pengertian (misunderstanding) yang pada

${ }^{13}$ Onong Uchjaya Effendy, Dinamika komunikasi, (Bandung: PT Remaja Rosdakarya, 2015) hlm. 11 
akhirnya bisa menimbulkan salah komunikasi (miscommunication). $\mathrm{H}$ al ini bisa di buktikan saat wawancara dengan pertanyaan,

"A pakah penah mengalami misscommunication?"

Yonas sorang driver GrabBike mengatakan,

"Pernah, M bak. Kalau saya khan (orang) Jawa Timur, Banyuwangi. Kalau dapet anak Bekasi atau anak Jakarta-an gitu suka kaku kalau ngomong. Jadi, saya pakai Bahasa Indonesia. Biasanya pakai Bahasa Jawa soalnya."

Jika driver atau customer tidak bisa mengatasi hambatan ini maka akan terjadi se buah salah paham dalam berkomunikasi. Salah satunya disebabkan oleh perbedaan bahasa.

3) Hambatan mekanis

Hambatan mekanis dijumpai pada media yang dipergunakan dalam melancarkan komunikasi. Dalam penelitian ini, media yang digunakan adalah smartphone yang digunakan driver dalam melakukan pelayanan terhadap customer. Seperti yang telah dijelaskan dalam wawancara dengan pertanyaan,

Gusti seorang driver ojek online mengatakan bahwa,

"Jadi masalah maps aja, lokasi penjemputan sama arah tujuan."

Aning, yang merupakan customer ojek online GrabBike, mengatakan bahwa,

"Kalau miskomunikasi mungkin ya masalah teknis aja sih. Kayak GPS gitu.

Tapi kalau masalah komunikasi nggak pernah sih. M asih lancar-lancar aja sih"

Dari penjelasan tersebut, hambatan mekanis yang terjadi dalam pola komunkasi driver ojek online GrabBike pada pelayanan customer ditimbulkan dari GPS atau maps yang digunakan driver sebagai sarana atau bantuan untuk menemukan titik lokasi penjemputan customer.

4) Hambatan ekologis

Hambatan ekologis terjadi disebabkan oleh gangguan lingkungan terhadap proses berlangsungnya komunikasi, jadi hambatan ekologis datangnya dari lingkungan. 
Dalam penelitian ini, hambatan ekologis pernah dilakukan atau pernah terjadi antara driver pada customer ataupun customer pada driver, seperti yang sudah dikatakan dalam wawancara.

H elmi, seorang customer ojek online GrabBike, mengatakan bahwa,

"Ya pernah. Kadang khan kalau di jalan kita nggak bisa denger dan drivernya udah ngomong berulang-ulang. Jadi, kita khan sungkan kalau nanyain lagi. Jadi ya cuman diiyain aja, karena nggak denger."

Rinda, yang juga seorang customer ojek online GrabBike, mengatakan bahwa,

"Khan soalnya pakai motor ya. Terus khan bising gitu kalau di jalan. Jadi nggak denger biasanya orangnya nanya apa. Jadi aku biasanya nanya lagi, tadi nanya apa Pak?”

Pada penjelasan ini, tidak bisa dipungkiri bahwa hambatan ekologis bisa terjadi bahkan akan sering terjadi karena proses yang terjadi antara driver dan customer terjadi di atas kendaraan bermotor.

\section{PEMBAHASAN}

Berdasarkan analisis penelitian yang telah dipaparkan sebelumnya, ditemukan bahwa pola komunikasi yang di gunakan oleh driver ojek online GrabBike pada pelayanan customer di Kota M alang adalah ketiga pola komunikasi, yaitu:

\subsection{Pola Komunikasi Linier atau Satu Arah}

Bentuk komunikasi ini dilakukan oleh driver ojek online GrabBike pada pelayanan customer di Kota Malang. Tidak semua driver melakukan pola komunikasi linier atau satu arah ini, tergantung bagaimana kondisi customer yang sedang dilayani ataupun kondisi driver. Dalam praktiknya, pola komunikasi linier atau satu arah ini dipengaruhi oleh hambatan-hambatan. Salah satunya adalah hambatan sosioantro-psikologis. hambatan ini terjadi karena kondisi psikis atau mood yang mempengaruhi komunikasi sehingga driver harus mengetahui kondisi yang sedang terjadi disaat melakukan komunikasi.

\subsection{Pola Komunikasi Sirkuler atau D ua Arah}


Bentuk komunikasi sirkuler atau dua arah ini yang sering dilakukan oleh driver ojek online GrabBike dalam melakukan pelayanan pasa customer di Kota Malang. Komunikasi sirkuler atau dua arah ini dirasa lebih efektif dari pada komunikasi lain saat driver melakukan pelayanan kepada customer. Driver maupun customer lebih nyaman saat melakukan komunikasi dua arah. Karena sebuah komuniksai akan dikatakan berhasil jika pesan yang disampaikan oleh komunikator dapat diterima, dipahami dan direspon dengan baik oleh komunikannya. $\mathrm{Hal}$ ini sering dilakukan oleh driver ojek online GrabBike pada pelayanan customer di Kota $M$ alang. A kan tetapi, kendala atau hambatan yang muncul juga tidak sedikit. Ada beberapa hambatan yang terjadi, di antaranya adalah hambatan mekanis atau hambatan yang dijumpai pada media yang dipergunakan dalam melancarkan sebuah komunikasi. Komunikasi antara driver dan customer sudah dilakukan saat driver mendapatkan order yaitu melalui aplikasi di smartphone. GPS yang tidak sesuai atau chat yang kurang baik dapat menimbulkan hambatan ini.

Yang berikutnya adalah hambatan semantis, hambatan semantis menyangkut bahasa yang dipergunakan komunikator sebagai alat untuk menyalurkan pikiran an perasaan kepada komunikan. Demi kelancaran komunikasi, komunikator harus memperhatikan gangguan semantis ini. Salah satu hambatan ini yang sering menghambat komunikasi sirkuler atau dua arah dimana driver harus bisa memahami apa yang disampaikan customer dan driver harus bisa mengimbangi bahasa yang digunakan oleh customer, entah pada penggunaan bahasa lokal maupun bahasa nasional.

Yang terakhir, hambatan yang juga sering muncul saat driver melakukan komunikasi dua arah adalah hambatan ekologis. Hambatan ini terjadi disebabkan oleh gangguan lingkungan terhadap proses berlangsungnya komunikasi. Jadi, hambatan ekologis datangnya dari lingkungan. $\mathrm{Hal}$ ini menjadi salah satu kendala yang utama karena komunikasi yang dilakukan driver ojek online GrabBike pada customer dilakukan di atas kendaraan bermotor yang otomatis lingkungan menjadi faktor utamanya. Saat menaiki kendaraan, terkadang suara (pesan) yang disampaikan tidak terlalu jelas dikarenakan ada angin atau lingkungan jalan yang bising. Hal-hal seperti itulah yang dapat menghambat terjadinya komunikasi sirkuler atau dua arah.

\subsection{Pola Komunikasi Helical atau Spiral}


Bentuk komunikasi helical atau spiral ini adalah komunikasi yang terjadi berkelanjutan. Oleh karena itu, pola komunikasi ini jarang terjadi di antara driver dan customer, tapi tidak menutup kemungkinan beberapa driver mengalamai pola komunikasi ini. Salah satu faktor yang bisa menunjang pola komunikasi ini adalah kenyamanan yang diciptakan oleh driver sehingga membuat customer ingin melakukan komunikasi yang lebih. Seperti contoh, jika seorang driver mendapatkan orderan offline setelah melakukan orderan online, ataupun driver yang melanjutkan perbincangan dengan customer melalui aplikasi chating. Disaat driver sudah menciptakan rasa nyaman, pola komunikasi helical atau spiral ini dapat terjadi.

\section{KESIMPULAN}

Berdasarkan analisis dan penyajian data yang sudah dilakukan, maka dapat disimpulkan bahwa pola komunikasi yang digunakan oleh driver ojek online GrabBike pada pelayanan customer di Kota Malang adalah ketiga pola tersebut, yaitu, pola komunikasi linier atau satu arah, pola komunikasi sirkuler atau dua arah, dan komunikasi helikal atau spiral.

Komunikasi yang pertama adalah pola komunikasi linier atau satu arah. Ini dilakukan oleh driver namun tidak banyak yang menerapkan. Yang kedua adalah pola komunikasi sirkuler atau dua arah. Pola komunikasi ini adalah pola komunikasi yang sering dilakukan oleh driver ojek online dalam melakukan pelayan kepada customer karena dinilai lebih akurat atau lebih baik dibanding komunikasi yang lain. Pola ini dianggap bisa menciptakan sebuah kesan baik kepada customer serta bisa membuat customer merasa nyaman saat ada di atas kendaraan. Pola komunikasi sirkuler atau dua arah ini yang nantinya mendukung terjadinya pola komunikasi helical atau spiral yang dilakukan setelah proses order selesai. Namun tidak banyak driver yang melakukan pola komunikasi helical atau spiral ini. Pola komikasi ini akan berjalan dengan baik saat driver dapat memahami dan mengatasi hambatan-hambatan yang bisa saja terjadi disaat proses komunikasi terjadi.

Berdasarkan dari hasil penelitian, ada beberapa saran yang dapat dilakukan yaitu Bagi penelti yang berminat untuk meneliti topik yang serupa dapat mengembangkan teori dari berbagai sumber guna menambah wawasan yang lebih dalam serta dapat menyempurnakan penelitian ini. Pertanyaan dalam wawancara di- 
anjurkan banyak menggunakan pertanyaan yang terbuka agar mendapatkan temuan baru serta gambaran yang lebih detail tentang bagaimana pola atau bentuk komunikasi yang digunakan oleh driver ojek online pada pelayanan customer.

Diharapkan masyarakat dapat memanfaatkan hasil penelitian ini sebagai wawasan baru untuk mengetahui lebih banyaj tentang bagaimana macam-macam pola komunikasi dan interaksi dalam melakukan pelayanan pada customer serta mengetahui dan memahami bagaimana hambatan-hambatan yang bisa terjadi saat proses komunikasi berlangsung. [] 


\section{REFERENCES}

\section{Buku :}

Effendy, Onong Uchjaya, 2006. IImu Komunikasi: Teori dan Praktek, Bandung: Penerbit PT Remaja Rosdakarya , 2015. Dinamika Komunikasi, Bandung: Penerbit PT Remaja Rosdakarya

Harapan, Edi, 2014. Komunikasi Antar Pribadi Perilaku Insani dalam Organisasi Pendidikan, Jakarta: Penerbit PT RajaGrafindo Persada

M achmud, M uslimin. 2016. Tuntunan Penulisan Tugas Akhir Berdasarkan Prinsip Dasar penelitian IImiah. M alang: Penerbit Selaras

M ulyana, Deddy. 2008. IImu Komunikasi : Suatu Pengantar. Bandung: Penerbit PT Rosdakarya

Nurrudin. 2017. IImu Komunikasi IImiah dan Populer, Jakarta: Penerbit PT RajaG rafindo Persada

Saifuddin, Azwar. 2015. M etode Penelitian. Yogyakarta: Penerbit Pustaka Pelajar.

Sugiyono. 2015. M etode Penelitian Kuantitatif Kualiatif dan R\&D. Bandung: Penerbit A lfabeta

\section{Jurnal :}

Anindhita, W iratri. 2016. "Analisis Penerapan Teknologi Komunikasi Tepat Guna Pada Bisnis Transportasi Ojek Online (Studi Pada Bisnis Gojek Dan Grab Bike Dalam Penggunaan Teknologi Komuniasi Tepat Guna Untuk M engembangkan Bisnis Transportasi”, dalam Prosiding Seminar Nasional INDOCOM PAC Universitas Bakrie

Chan, Arianis, Maulydia Maharani, dan Pratami Wulan Tresna, 2017. "comparison of user experience on go-jek and grab mobile apps (study on pt. Go-jek and pt. Grab indonesia consumer in dki jakarta", dalam Jurnal AdBispreneur Vol. 2, N o. 2, Agustus 2017 
Lumentut, Gracia, 2017. “Pola Komunikasi Pemimpin Organisasi Dalam M eningkatkan M otivasi Kerja Anggota Di LPM (Lembaga Pers M ahasiswa) Inovasi Unsrat", dalam Acta Diurna, Vol. I, N o. 1, tahun 2017

Rafael \& Billy, 2013. "Pengaruh Harga Dan Promosi Grab Terhadap Brand Image Yang Mempengaruhi Keputusan Pembelian Konsumen Pengguna Transportasi Berbasis Online", dalam Jurnal Riset M anajemen dan Bisnis (JRM B) Fakultas Ekonomi UNIAT, V ol. 1. N o. 3 tahun 2013

Rahmawati, A mrina, 2013. "Pola Komunikasi Pemandu W isata (Guide) Kampung Wisata Batik Kauman Surakarta”, dalam Rural and Development, Vol. I, No. I, Tahun 2013

Rifaldi, Kadunci \& Sulistyowati, 2016. "Pengaruh Kualitas Pelayanan Transportasi Online Gojek Terhadap Kepuasan Pelanggan Pada Mahasiswa/I Administrasi Niaga Politeknik Negeri Jakarta", dalam Jurnal Epigram, Vol. II, No. 3, Tahun 2016 